\title{
Genotypic Characterization of Shigella Species Isolated from Abattoirs in the North West Province, South Africa Using PCR Analysis
}

\author{
Innocentiah Ntshepang Makabanyane ${ }^{1}$, Rendani Victress Ndou ${ }^{2}$, Collins Njie Ateba ${ }^{1{ }^{* *}}$ \\ ${ }^{1}$ Department of Biological Sciences, School of Environmental and Health Sciences, Faculty of Agriculture, Science and Technology, \\ North West University- Mafikeng Campus, Private Bag X2046, Mmabatho 2735, South Africa \\ ${ }^{2}$ Centre for Animal Health Studies, School of Agricultural Sciences, Faculty of Agriculture Science and Technology, North-West \\ University - Mafikeng Campus, P. Bag X2046 Mmabatho 2735, South Africa \\ *Corresponding author: atebacollins1@hotmail.com
}

Received May 14, 2014; Revised November 14, 2014; Accepted February 26, 2015

\begin{abstract}
Foodborne pathogens pose a serious threat to food safety especially in developing countries where hygiene facilities are not well developed and operational practices in abattoirs and retail shops are often poor. Shigella species are known to cause foodborne complications in humans including shigellosis that is not only characterized by destruction of the epithelium of the colon but usually results to an inflammatory response. The transmission of Shigella species to humans most often results through the consumption of contaminated food, meat and water. The aim of this study was to isolate and identify Shigella species from carcass of cattle in some abattoirs in the North West Province, South Africa and determine the virulence gene profiles of the isolates using PCR assays. A total of 97 carcass swabs were obtained from the abattoirs that were sampled. Swabs were properly labeled and transported on ice to the laboratory for analysis. The swabs were washed in $2 \%(\mathrm{w} / \mathrm{v})$ peptone water and plated on Salmonella-Shigella agar. Standard identification tests (Gram staining, oxidase test, TSI test and 16S rRNA) were used to confirm the identities of 97 (one from each sample) presumptive isolates. Large proportions (85\% to 100\%) of the isolates from Rustenburg and Zeerust were oxidase positive. None of the isolates produced hydrogen sulphide gas on TSI medium but utilize glucose as a source of carbon. A large proportion (75.3\%) of the isolates was positively identified as Shigella species based on PCR analysis. The number of isolates confirmed as Shigella species was higher in Zeerust (54.8\%) than in Rustenburg (45.2\%). Shigella species were most often isolated from samples that were collected outside than inside the carcass. Generally a large proportion (74.0\%) of the isolates possessed the IpaH gene while64.4\% of these isolates were positive for the IpaBCD gene that encodes for the invasion plasmid antigen. An analysis of the isolates from the different sampling sections indicated that $46.3 \%$ and $55.3 \%$ of the isolates from Zeerust possessed the IpaH and the IpaBCD genes, respectively while $53.7 \%$ and $44.7 \%$ of the isolates from Rustenburg possessed these genes. The detection of virulent Shigella species in beef carcasses demonstrates the need for a continued surveillance of this pathogen in meat in order to ensure the implementation of improved food safety measures.
\end{abstract}

Keywords: Shigella species, abattoir, carcass, beef, PCR analysis, IpaH, IpaBCD

Cite This Article: Innocentiah Ntshepang Makabanyane, Rendani Victress Ndou, and Collins Njie Ateba, "Genotypic Characterization of Shigella Species Isolated from Abattoirs in the North West Province, South Africa Using PCR Analysis." Journal of Food and Nutrition Research, vol. 3, no. 2 (2015): 121-125. doi: 10.12691/jfnr-3-2-8.

\section{Introduction}

Foodborne pathogens pose a serious threat to food safety especially in developing countries where hygiene facilities and operational practices in abattoirs and retail shops are often properly implemented. Recently, the incidence of foodborne infections have greatly increased worldwide and it is estimated that nearly a quarter of the population is at risk [1,2]. In most cases where foodborne infections and outbreaks occur in humans, meat and its related products are usually identified as the sources of contamination [3,4,5,6,7]. Shigella species are Gramnegative, non-spore forming, non-motile, non-lactose fermenting, facultative anaerobic bacteria that inhabit the gastrointestinal tract of humans and warm blooded animals. These organisms are amongst the major foodborne pathogens currently known and are therefore frequently isolated from infected patients [8,9,10]. Infections caused by Shigella species include bacillary dysentery which is endemic throughout the world and it is responsible for approximately 165 million cases annually, of which 163 million occur in developing countries and 1.5 million in industrialized ones [11]. In addition 1812 
cases of both invasive and non-invasive shigellosis has been reported in South Africa and the incidence was high among children who below 5 years of age [12]. Therefore foodborne infections caused by these organisms are of major international health concern [8]. The differentiation of Shigella species is mainly based on serotyping and biochemical assays [9]. S. dysenteriae, S. flexineri and $S$. boydii are physiologically similar but $S$. sonnei can be differentiated using metabolic assays [13]. These three Shigella species are most often implicated as agents of human disease worldwide [14]. In addition S. dysenteriae is known to cause epidemics of dysentery, particularly in confined populations such as refugee camps [14].

Several PCR protocols using different molecular markers have been used for the detection of Shigella species in environmental, faecal, and food samples [15-22]. The invasion plasmid antigen $\mathrm{H}(\mathrm{IpaH})$ and the IpaABCD genes are virulence gene markers whose protein products are necessary for invasion of colonic epithelial cells. These target genes are reliable for the detection of Shigella species in food and environmental samples $[15,17,19]$. These genetic markers are carried by all four Shigella species [15].

In the meat industry public health regulatory policies are designed and proposed to be implemented to ensure food safety [23]. Safe food products will greatly meet the high expectations of consumers [23]. Unfortunately, meat can be contaminated through contact with the working surfaces and the equipments at the time of slaughter and if processed in unhygienic conditions [24]. Contamination of carcasses and the environment in abattoirs with intestinal contents of cattle is known to be a critical risk factor for the transmission of pathogens to humans [25]. It is therefore important to ensure that measures are put in place to prevent contamination of meat with foodborne pathogens including Shigella species. This can also be achieved through the implementation of surveillance network programs. The present study was therefore designed to investigate the level of contamination of carcasses in selected abattoirs by Shigella species.

\section{Materials and Methods}

\subsection{Area of the Study}

The research was conducted in the North-West University (Mafikeng campus) - North-West Province, South Africa. Meat samples were obtained from different abattoirs in the North-West Province. This consisted of 97 samples both from Rustenburg and Zeerust.

\subsection{Sample Collection}

The samples were collected by swabbing meat carcasses inabattoirs. Prior to collection of samples, hand cloves were worn and swaps were used to collect samples from inside and outside the carcasses. Swabs were placed in transport media, labeled properly and immediately transported on ice to the laboratory for analysis.

\subsection{Selective Isolation of Shigella Species}

Swabs were washed in $5 \mathrm{~mL}$ of $2 \%(\mathrm{w} / \mathrm{v})$ peptone water, and $100 \mu \mathrm{L}$ of the sample mixture was spread-platedon the
Salmonella-Shigella agar (SSA) and incubated aerobically at $37^{\circ} \mathrm{C}$ for 24 hours. Two to three characteristic colonies were sub-cultured on SSA plates and the plates were incubated at $37^{\circ} \mathrm{C}$ for 24 hours. Pure isolates were retained for identification using specific biochemical tests.

\subsection{Bacterial Identification}

\section{Cellular morphology}

The isolates were Gram stained using a standard method [26]. All Gram-negative rods were subjected to primary and secondary identification tests.

\subsection{Preliminary Biochemical Identification Tests for Shigella Species}

\subsubsection{Oxidase Test}

Oxidase test was performed on all isolates using the oxidase test reagent from Pro-Lab Diagnostics - United Kingdom.

\subsubsection{Triple Sugar Iron Agar Test}

The Triple sugar iron (TSI) agar (Bio-Lab) obtained from Merck, South Africa was used to assay the potential of isolates in utilizing the three sugars; glucose, sucrose and lactose present at final concentrations 0.1, 1.0 and $1.0 \%$, respectively. Results were interpreted using previously recommended procedure [27].

\subsubsection{Extraction of Genomic DNA}

Bacterial genomic DNA was extracted using the Boiling method [28]. Aliquots of $500 \mu \mathrm{L}$ distilled water were placed in Eppendorf tubes and pure colonies of isolates were used to prepare bacteria suspensions. The tubes were vortexed and heated in a dry bath at $100{ }^{\circ} \mathrm{C}$ for 15 minutes. The contents were centrifuged at $13500 \mathrm{rpm}$ for 2 minutes and the supernatant was transferred into a new Eppendorf tubes. An aliquot of $5 \mu \mathrm{L}$ from each supernatant was used for the PCR assay.

\subsection{PCR for the Identification of Shigella Species and Their Associated Virulence Genes}

Standard $25 \mu \mathrm{L}$ PCR reactions were performed to amplify bacteria 16S rRNA [29], IpaH gene fragments [16] and Shigella species virulence gene [16] fragments using oligonucleotide primer sequences that occur in Table 1. The reaction mixture consisted of $5 \mu \mathrm{L}$ of template DNA, $12.5 \mu \mathrm{L}$ of master-mix, $1.5 \mu \mathrm{L}$ of reaction buffer, $1.5 \mu \mathrm{L}$ of the $\mathrm{MgCl}_{2}, 0.5 \mu \mathrm{L}$ of both oligonucleotide primers, and $4 \mu \mathrm{L}$ of nuclease free water. The primers were synthesized by Inqaba Biotec Pty Ltd, Pretoria, South Africa and all PCR reagents were obtained from Fermentas, USA.

Table 1. Oligonucleotide primer sequences used for PCR analysis of Shigella species

\begin{tabular}{|c|c|c|}
\hline Primer & Sequence (5' - 3') & Target Gene \\
\hline Sh16S-F & AGACTGCTACGGGAGGCAGCAGT & \multirow{2}{*}{$\begin{array}{l}16 \text { rRNA gene } \\
\text { fragment }\end{array}$} \\
\hline Sh16S-R & GTTGCGCTCGTTGCGGGACTTAA & \\
\hline IpaH-F & GCTGGAAAAACTCAGTCCT & \multirow{2}{*}{$\begin{array}{c}\text { IpaH virulence } \\
\text { gene for Shigella } \\
\text { species }\end{array}$} \\
\hline IpaH-R & GCTGGAAAAACTCAGTCCT & \\
\hline IpaBCD-F & GCTATAGCAGTGACATG & \multirow{2}{*}{$\begin{array}{c}\text { IpaBCD virulence } \\
\text { gene Shigella } \\
\text { species }\end{array}$} \\
\hline IpaBCD-R & ACGAGTTCGAAGCACTC & \\
\hline
\end{tabular}




\subsection{Electrophoresis of PCR Products}

The PCR products were resolved by electrophoresis on a $2 \%(\mathrm{w} / \mathrm{v})$ agarose gel. A horizontal Pharmacia biotech equipment system (model Hoefer HE 99X; Amersham Pharmacia biotech, Sweden) was used to carry out electrophoresis and this was run for 2 hours at $80 \mathrm{~V}$ using 1X TAE buffer (40mM Tris, $1 \mathrm{mM}$ EDTA and $20 \mathrm{mM}$ glacial acetic acid, PH 8.0). Each gel contained a 100 bp DNA molecular weight marker (Fermentas, USA). The gels were stained in ethidium bromide $(0.001 \mu \mathrm{g} / \mathrm{ml})$ for 15 minutes and the amplicons were visualized under UV light [30]. A Gene Genius Bio Imaging System (Syngene, Synoptics; UK) was used to capture the images using GeneSnap (version 6.00.22) software. GeneTools (version 3.07.01) software (Syngene, Synoptics; UK) was used to analyze the images in order to determine the relative sizes of the amplicons.

\section{Results and Interpretation}

\subsection{Occurrence of Shigella Species in Meat Carcasses from the Abattoirs}

A total number of 97 beef carcass swab samples that comprised 46 and 51 from abattoirs in Rustenburg and Zeerust respectively were analysed for the characters of Shigella species using preliminary identification tests that are specific for the Enterobacteriaceae (Gram staining, oxidase test and the triple sugar iron agar test). The proportion of isolates that satisfied the preliminary identification criteria for Shigella species are shown in Table 2. As shown in Table 2, all the isolates from Zeerust and Rustenburg were Gram negative rods. All the isolates from Zeerust and a large proportion (85\%) of those from Rustenburg were oxidase positive. None of these isolates was able to produce hydrogen sulphide gas from the TSI medium but they were all able to utilize glucose as a source of carbon. These results indicate the possibility of cross contamination during the processing of meat. However, the contamination of the beef carcass may have resulted through contact of the carcass with the hides of animals. This therefore amplifies the need to improve on farm management techniques in the area.

Table 2. Proportion of isolates that were positive for preliminary identification tests of Shigella species

\begin{tabular}{|l|c|c|c|c|c|c|}
\hline \multirow{2}{*}{ Sample site } & \multirow{2}{*}{$\begin{array}{c}\text { GS } \\
\text { (-ve rod) }\end{array}$} & \multirow{2}{*}{$\begin{array}{c}\text { OT } \\
\text { (+ve) }\end{array}$} & $\begin{array}{c}\text { LFT } \\
\text { (+ve) }\end{array}$ & $\begin{array}{c}\text { GFT } \\
\text { (+ve) }\end{array}$ & $\begin{array}{c}\mathbf{H}_{2} \mathbf{s} \\
\text { (-ve) }\end{array}$ & $\begin{array}{c}\text { Gas } \\
\text { (+ve) }\end{array}$ \\
\hline Rustenburg & $21^{\mathrm{a}}$ & 16 & 14 & 21 & 21 & 18 \\
\hline & $25^{\mathrm{b}}$ & 23 & 20 & 25 & 25 & 21 \\
\hline Total No. & $\mathbf{4 6}$ & $\mathbf{3 9}$ & $\mathbf{3 4}$ & $\mathbf{4 6}$ & $\mathbf{4 6}$ & $\mathbf{3 9}$ \\
\hline Zeerust & $23^{\mathrm{a}}$ & 23 & 18 & 23 & 23 & 20 \\
\hline & $28^{\mathrm{b}}$ & 28 & 22 & 28 & 28 & 26 \\
\hline Total No. & $\mathbf{5 1}$ & $\mathbf{5 1}$ & $\mathbf{4 0}$ & $\mathbf{5 1}$ & $\mathbf{5 1}$ & $\mathbf{4 6}$ \\
\hline
\end{tabular}

${ }^{a}$ Inside the carcass; ${ }^{b}=$ Outside the carcass

\subsection{Confirmatory Identification Presumptive Shigella Species Using Specific 16S rDNA PCR Analysis}

A total number of 97 isolates that comprised 46 and 51 from beef carcass in abattoirs in Rustenburg and Zeerust, respectively were subjected to specific PCR analysis for characters of Shigella species using specific primer sequences. The number of isolates tested and those that were positive for the 16S rDNA gene fragment are shown in Table 3. As shown in Table 3, a large proportion (75.3\%) of the isolates was positively identified. The proportion of isolates was generally higher in samples obtained from outside than inside the carcass of animals. Moreover, the number of isolates confirmed as Shigella species was higher in samples obtained from abattoirs in Zeerust (54.8\%) than in Rustenburg (45.2\%).

Table 3. Proportion of isolates that were positive for 16S rDNA species specific PCR for Shigella

\begin{tabular}{|c|c|c|c|}
\hline Sample site & $\begin{array}{c}\text { Sampling } \\
\text { No. / } \\
\text { Position } \\
\end{array}$ & $\begin{array}{c}\text { No. of isolates } \\
\text { positively } \\
\text { identified }\end{array}$ & $\begin{array}{c}\text { \% of isolates } \\
\text { positively } \\
\text { identified }\end{array}$ \\
\hline \multirow[t]{2}{*}{$\begin{array}{c}\text { Rustenburg } \\
(\mathrm{NT}=46)\end{array}$} & $\begin{array}{c}\text { Inside } \\
(\mathrm{NT}=21)\end{array}$ & 14 & $19.2 \%$ \\
\hline & $\begin{array}{c}\text { Outside } \\
(\mathrm{NT}=25)\end{array}$ & 19 & $26.0 \%$ \\
\hline \multirow[t]{2}{*}{$\begin{array}{c}\text { Zeerust } \\
(\mathrm{NT}=51)\end{array}$} & $\begin{array}{c}\text { Inside } \\
(\mathrm{NT}=23)\end{array}$ & 18 & $24.7 \%$ \\
\hline & $\begin{array}{c}\text { Outside } \\
(\mathrm{NT}=28)\end{array}$ & 22 & $30.1 \%$ \\
\hline Total & 97 & 73 & $100 \%$ \\
\hline
\end{tabular}

\subsection{PCR Analysis of Virulence Genes of Shigella Species}

All the 73 isolates that were positively identified as Shigella species were subjected to PCR for the detection of IpaH gene and the IpaBCD virulence genes. Results for the IpaH and IpaBCD PCR assays are shown on Tables 4. Large proportions (74.0\%) of the isolates from Rustenburg and Zeerust possessed the invasion gene IpaH. Moreover, a similarly large proportion (64.4\%) of the isolates harboured the IpaBCD gene that encodes for the invasion plasmid antigen. An analysis of the isolates from both sampling sites indicated that $46.3 \%$ and $55.3 \%$ of the isolates from Zeerust possessed the IpaH and the IpaBCD genes, respectively while $53.7 \%$ and $44.7 \%$ of the isolates from Rustenburg possessed these genes.

Table 4. Proportion of isolates that were positive for IpaH and IpaBCD virulence gene specific PCR analysis

\begin{tabular}{|l|c|c|c|c|c|}
\hline Sample site & $\begin{array}{c}\text { Sampling } \\
\text { No. / } \\
\text { Position }\end{array}$ & \multicolumn{2}{|c|}{$\begin{array}{c}\text { No. of isolates } \\
\text { positively } \\
\text { identified }\end{array}$} & \multicolumn{2}{|c|}{$\begin{array}{c}\text { \% of isolates } \\
\text { positively } \\
\text { identified }\end{array}$} \\
\hline & & IpaH & IpaBCD & IpaH & IpaBCD \\
\hline $\begin{array}{l}\text { Rustenburg } \\
\text { (NT=33) }\end{array}$ & $\begin{array}{c}\text { Inside } \\
\text { (NT=14) }\end{array}$ & 12 & 8 & $22.2 \%$ & $17.0 \%$ \\
\hline & $\begin{array}{c}\text { Outside } \\
\text { (NT=19) }\end{array}$ & 17 & 13 & $31.5 \%$ & $27.7 \%$ \\
\hline $\begin{array}{l}\text { Zeerust } \\
\text { (NT=42) }\end{array}$ & $\begin{array}{c}\text { Inside } \\
\text { (NT=18) }\end{array}$ & 7 & 15 & $13.0 \%$ & $31.9 \%$ \\
\hline & $\begin{array}{c}\text { Outside } \\
\text { (NT=22) }\end{array}$ & 18 & 11 & $33.3 \%$ & $23.4 \%$ \\
\hline Total & $\mathbf{7 3}$ & $\mathbf{5 4}$ & $\mathbf{4 7}$ & $\mathbf{1 0 0} \%$ & $\mathbf{1 0 0 \%}$ \\
\hline
\end{tabular}

\section{Discussions}

Food products of animal origin including meat are currently known to be the main vehicle for the transmission of pathogens to humans [31]. Shigellosis is endemic in most developing countries and causing 
hundreds of deaths yearly [32] and a number of outbreaks have resulted from the consumption of contaminated food even in countries with more advanced public health facilities [33,34,35]. Moreover, opportunities for the transmission of pathogens from contaminated food products to humans are further enhanced when these products are consumed undercooked [37]. By implication it is very crucial to determine the level of contamination of meat in abattoir settings. This may provide valuable information that could be used to prevent contamination of carcass and consequently meat products during processing.

The primary objective of this study was to isolate and identify Shigella species from meat carcasses obtained from abattoirs in the Zeerust and Rustenburg in the North West Province, South Africa. This was motivated from the fact that other pathogenic foodborne bacteria strains have been isolated from meat in the North West province [37]. Moreover, it is evident that the presence of these bacteria cells in carcass in abattoirs can serve as a potential source for the isolates to be transmitted to humans and cause gastrointestinal diseases if the meat products are not cooked properly before they are eaten $[8,33,34,35,36]$. In the present study, Shigella species were detected in 73/97 (75.3\%) of the samples analysed. These finding are even higher than those reported in other countries [38,39,40]. In Egypt, $2.0 \%$ of meat products were positive for Shigella species [38] while only a $0.6 \%$ prevalence rate was detected in meat products analysed in Ethiopia [39]. On the contrary, none of the meat samples analysed in a study conducted in Turkey were positive for the pathogen [40]. However, live animals present in an abattoir at a particular time may not be the only reservoir of Shigella species and therefore during the processing of meat, bacteria that were present in the hides and faeces of previously processed animals may have contaminated the equipments in the abattoir [41]. These contaminants can then be transported to the carcass of subsequent animals. In addition the prevalence rate of Shigella species in the current study is very high and this suggests the need to strengthen food safety control systems in abattoirs.

In the present study, a genetic PCR assay was used to also detect Shigella species specific virulence genes in isolates obtained from beef carcasses in the North West Province. Results obtained were similar to a previous study in which the IpaH gene and the IpaBCD were used as indicators to assess the health impacts of Shigella species in humans [16]. Large proportions (64.4\% and $74.0 \%$ ) of the isolates from Rustenburg and Zeerust possessed the IpaBCD genes and the invasion gene IpaH respectively. It has been suggested that environmental Shigella isolates tend to lose some of their plasmidencoded invasion genes since they may not have any known functions as compared to when they are found in the gastrointestinal tract of their hosts [16]. On the contrary, the chromosomally located multicopy virulence genes, ipaH, which is also known to play a role in producing bacteria invasive characteristics [16] is usually more stable and present in a large proportion of Shigella isolates. Similar findings were reported in the present study and the latter may account for this observation.

It is currently estimated that infections caused by Shigella species affect about 164.7 million people worldwide resulting to about 1.1 million death cases [42]. Given the easy with which Shigella species contaminate several types of food products, its transmission to humans is also easily achieved [43]. Similar to most foodborne pathogenic microorganisms the infectious dose of Shigella species is very low and epidemiological data reveal that approximately 10 bacteria cells can successfully cause disease [43]. Given that this amount of cells can be easily consumed in contaminated food it is therefore important to implement control strategies that would limit the transmission of these cells to food products.

\section{Conclusion}

The present study examined the level of contamination of beef carcasses in abattoirs with Shigella species. Results indicated the presence of pathogenic strains that can be transmitted to humans if the food products are consumed undercooked. This amplifies the need to implement proper regulatory policies in abattoirs to limit the health implications of these pathogens on consumers.

\section{Acknowledgement}

We gratefully acknowledge Mr. B.J Morapedi for his assistance during the collection of samples and Mrs Huyser Rika for technical assistance during this study. This study was financially supported by Department of Biological Sciences, North West University and the North West University Postgraduate Merit Bursary.

\section{References}

[1] Oliver, S.P., Jayarao, B.M. and Almeida, R.A., "Foodborne pathogens in milk and the dairy farm environment: food safety and public health implications”. Foodborne Pathog Dis 2. 115-129. 2005.

[2] Centre for Disease Control., "Incidence and trends of infection with pathogens transmitted commonly through food - foodborne diseases active surveillance network, 10 U.S sites, 1996 - 2012”. Wkly Rep 62(15). 283-287. 2013.

[3] DuPont, HL, et al., "Inoculum Size in Shigellosis and Implications for expected mode of transmission,” Journal of Infectious Diseases, Vol. 159, No. 6, pp. 1126-28. 1989.

[4] Wu, F.M., Doyle, M.P., Beuchat, L.R., Wells, J.G., Mintz, E.D. and Swaminathan, B., "Fate of Shigella sonnei on parsley and methods of disinfection”. J Food Prot63. 568-572. 2000.

[5] Williams, R. C., Isaacs, S., Decou, M. L., Richardson, E. A., Buffet, M. C., Slinger, R. W., Brodsky, M. H., Ciebin, B. W., Ellis A., and Hockin, J., "Illness outbreak associated with Escherichia coli O157:H7 in Genoa salami”. Can Med Assoc J 162. 1409-1413. 2000.

[6] Sim, J., Hood, D., Finnie, L., Wilson, M., Graham, C., Brett, M. and Hudson, J.A., "Series of incidents of Listeria monocytogenes non-invasive febrile gastroenteritis involving ready-to-eat meats". Lett Appl Microbiol 35. 409-413. 2002.

[7] Kosmider,R.D., Nally, P’., Simons, R.R.L., Brouwer, A., Cheung, S., Snary, E.L. and Wooldridge, M., "Attribution of human VTEC O157 infection from meat products: a quantitative risk assessment approach. Risk Anal 30. 753-765. 2010

[8] Mensah, D. Yeboah-Manu, K. Owusu-Darko, A. Ablordey. "Street foods in Accra, Ghana: how safe are they?"Bull World Health Org 80. 546-553. 2002.

[9] Nakazato, A., Momoi, Y., Kadoya, M. and Iwasaki, T., "Measurement offeline serum interleukin-5 level". J Vet Med Sci 69. 843-846. 2007.

[10] Centre for Disease Control., "Preliminary FoodNet data on the incidence of infection with pathogens transmitted commonly through food -10 states, 2009'. Morb Mortal Wkly Rep 59. 418422. 2010. 
[11] Sharma, A., Singh, S.K., Bajpai, D., "Phenotypic and genotypic characterization of Shigella spp. with reference to its virulence genes and antibiogram analysis from river Narmada”. Microbiol Res 165. 33-42. 2010

[12] Keddy, K.H., Sooka, A., Crowther-Gibson, P., Quan, V., Meiring, S., Cohen, C., Nana, T., Sriruttan, C., Seetharam, S., Hoosen, A., Naicker, P., Elliott, E., Haffejee, S., Whitelaw, A., Klugman, K.P., Group for Enteric, Respiratory, and Meningeal Disease Surveillance in South Africa (GERMS-SA)., "Systemic shigellosis in South Africa”. Clin Infect Dis 54. 1448-54.2012

[13] Uyttendaele M., Bagamboula, C.F.,De Smet, E.,Van Wilder, S. andDebevere, J.,"Evaluation of culture media for enrichment and isolation of Shigella sonnei and S. flexneri". IntJ Food Microbiol 70. 255-265. 2001.

[14] World Health Organisation, "Sixty-third World Health Assembly. Document WHA63/A63/11”. 2012. Available at http://www.apps.who.int/gb/ebwha/pdf_files/WHA63/A63_11en.pdf.

[15] Theron, J., Morar, D., Du Preez, M., Br"ozel, V.S., and Venter, S.N., "A sensitive seminested PCR method for the detection of Shigella in spiked environmental water samples”. Water Res35. 869-874. 2001.

[16] Faruque, S.M., Khan, R., Kammuzzaman, M., et al, "Isolation of Shigella dysenteriae type 1 and S.flexneri strains from surface water in Bangladesh; comparative molecular analysis of environmental Shigella versus clinical strains”. Appl Environ Microbiol68(8). 3908-3913. 2002.

[17] Jin, Q., Yuan, Z., Xu, J.,Wang, Y., Shen, Y., Lu,W.,Wang, J., Liu, H., Yang, J., Yang, F., Zhang, X., Zhang, J., Yang, G., Wu, H., Qu, D., Dong, J., Sun, L., Xue, Y., Zhao, A., Gao, Y., Zhu, J., Kan, B., Ding, K., Chen, S., Cheng, H., Yao, Z., Bingkun, H., Chen, R., Ma, D., Qiang, B.,Wen, Y., Hou, Y. and Yu, J., "Genome sequence of Shigella flexneri 2a: insights into pathogenicity through comparison with genomes of Escherichia coli K12 and O157”. NucleicAcids Res30. 4432-4441. 2002.

[18] Lampel, K.A. and Orlandi, P.A., "Polymerase chain reaction detection of invasive Shigella and Salmonella enterica in food". Meth Mol Biol179. 235-244. 2002.

[19] Peng, X., Luo, W., Zhang, J., Wang, S., and Lin, S., "Rapid detection of Shigella species in environmental sewage by an immunocapture PCR with universal primers". Appl Environ Microbiol68. 2580-2583. 2002.

[20] Sapsford, K.E., Rasooly, A., Taitt, C.R. and Ligler, F.S. "Detection of Campylobacter and Shigella species in food samples using an array biosensor”. Anal Chem76. 433-440. 2004.

[21] Moganedi, K.L.M., Goyvaerts, E.M.A., Venter, S.N. and Sibara, M.M., "Optimisation of the PCR-invA primers for the detection of Salmonella in drinking and surface waters following a precultivative step”. Water SA 33(2).195-201. 2007.

[22] Penatti, M.P.A., Hollanda, L.M., Nakazato, G., Campos, T.A., Lancellotti, M., Angellini, M., Brocchi, M., Rocha, M.M.M. and Dias da Silveira, W., "Epidemiological characterization ofresistance and PCR typing of Shigellaflexneri and Shigella sonnei strainsisolated from bacillary dysentery casesin Southeast Brazil”. Braz J Med Biol Res 40. 249-258. 2007

[23] Govindarajan, C.V.,"Maintenance of hygiene and sanitary conditions including personal hygiene in the meat factory. Technical paper in First National Seminar on Marketing of Meat Food Products in India, Aaligarh, India.1990.

[24] Lues, J.F.R, Theron, M.M, Venter, P. and Rasephei, M.H.R., "Microbial composition of bioaerosols of a high-throughput chicken slaughtering facility”. Poultry Sci86. 142-149. 2007.
[25] Mead, P.S. and Griffin, P.M., “Escherichia coli O157:H7”. Lancet 352. 1207-1212. 1998.

[26] Cruikshank, R., Duguid, J.P., Marmoin, B.P., Swain, R.H. (1975). Medical Microbiology, $12^{\text {th }}$ ed. Longman, New York. (2): 3-4.

[27] Forbes, A.B. and Weissfeld, A.S., "Bailey and Scott's Diagnostic Microbiology”, 10th edn. Mosby, StLouis, MO. 1998.

[28] Tunung, R., Chai, L.C., Usha, M.R., Lee, H.Y., Fatimah, A.B. Farinazleen, M.G. and Son, R., "Characterization of Salmonella enterica isolated from street food and clinical samples in Malaysia”. ASEAN Food J 14(3). 161-173. 2007.

[29] Villalobo, E., and Torres, A., "PCR for detection of Shigella spp. in mayonnaise”. Appl Environ Microbiol 64. 1242-1245. 1998.

[30] Sambrook, J; Fritsch, E.F. and Maniatis, T. Molecular Cloning: a laboratory manual. 2nd ed. N.Y., Cold Spring Harbor Laboratory, Cold Spring Harbor Laboratory Press, 1989. 1659 p.

[31] European Food Safety Authority.,"The European Union summary report on trends and sources of zoonoses,zoonotic agents and food-borne outbreaks in 2011”. EFSA J11(4). 3129. 2013.

[32] World Health Organization Shigellosis: disease burden, epidemiology and case management. Wkly Epidemiol Rec 80. 9499. 2005

[33] Mead, P.S., L. Slutsker, V. Dietz, L.F. Mccaig, J.S. Bresee, C. Shapiro,et al.Food-related illness and death in the United States. Emerg Infect Dis 5. 607-625. 1999.

[34] Greig, J.D., Todd, E.C., Bartleson, C.A. and Michaels, B.S., "Outbreaks where food workers have been implicated in the spread of foodborne disease. Part 1 Description of the problems, methods, and agents involved". J Food Prot 70. 1752-1761. 2007.

[35] Anonymous., "Shigella - 2009. Travel and Migrant Health Section, Health Protection Agency, Colindale, UK (Published November 2011, available at http://www.hpa.org.uk/webc/HPAweb_C/1317131651978.

[36] Lampel, K.A., Jagow, J.A.,Trucksess, M. and Hill, W.E., "Polymerase chain reaction for detection of invasive Shigella flexneri in food". Appl Environ Microbiol 56.1536-1540. 1990.

[37] Ateba, C.N. and Mbewe, M.,"Detection of E. coli O157:H7 virulence genes in isolates from beef, pork, water, humans and animal species in the North West Province, South Africa: public health implications”. Res Microbiol 128. 181-188.2011.

[38] Ahmed, A.M. and Shimamoto, T., "Isolation and molecular characterisation of Salmonella enterica, Escherichia coli O157:H7 and Shigella spp. from meat and dairy products in Egypt”. Int $J$ Food Microbiol 168-169. 57-62. 2014.

[39] Tassew, H., Abdissa, A., Beyene, G. and Gere-Selassie, S., "Microbial flora and foodborne pathogens on mince meat and their susceptibility to antimicrobial agents". Ethiop J Health Sci 20. 137-143. 2010.

[40] Centinkaya, F., Cibik, G., Soyuteniz, E., Ozkin, C., Kayali, R. and Levent, B., "Shigella and Salmonella contamination in various foodstuffs in Turkey”. Food Cont 19. 1059-1063. 2008.

[41] Jackson, T.C., Marshall, D.L., Acuff, G.R. and Dickson, J.S., "Meat, poultry, and seafood, In Doyle, M.P., Beuchat, L.R., Montville, T.J. (Eds.), Food Microbiology: Fundamentals and Frontiers, 2nded. ASM Press, Washington DC, USA, pp 91-109.

[42] Thiem, V.D., Sethabutr, O., von Seidlein, L., Tung, T.V., Canh, D.G.,Chien, BT., Tho, L.H., Lee, H., Houng, H., Hale, T.L., Clemens, J.D.Mason, C. and Trach D.D.,"Detection of Shigella by a PCR assay targeting the ipaH gene suggests increased prevalence of shigellosis in Nha Trang, Vietnam”. J Clin Microbiol 42. 2031-2035. 2004.

[43] Wachsmuth, K. and Morris G.K., "Shigella, pp 448-660. In M.P. Doyle (ed.), Foodborne becterial pathogens. Marcel Dekker, Inc., New York, USA.1989. 